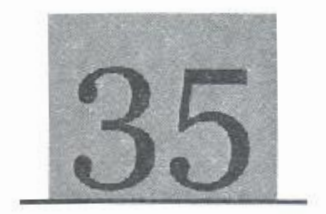

\title{
Assessment of the bacteriological profile of water and fish samples from Hadejia Reservoir in Jigawa State
}

\author{
Atiribom, R. Y./ Kolndadacha, O.D.
}

\begin{abstract}
Hadejia reservoir is a floodplain complex in northeastern Nigeria. This area has inng been noted for its importance in fish production. It is also important to both year round native birds and European water birds that travel over the Sahara desert to this wetland to spend their winters. Quantitative and qualitative profile of bacteria in the reservoir was carried out. Quantitative analysis of bacteria in the water revealed that the water contained totai heterotrophic count (THC) of $3.1 \times 10^{3}$ CHLimi to $3.5 \times 10^{6}$ cfulml and total coliform count (TCC) ranging from $1.4 \times 10^{2}$ to $1.4 \times 10^{7} \mathrm{CFU/mi}$. Bacteria load in the fish intestines were $3.5 \times 10^{3} \mathrm{CFU} / \mathrm{g}$ and $3.1 \times 10^{4} \mathrm{CFU} / \mathrm{g}$ for total coliform and total heteratrophic count respectively. Fish gills had less count $\left(2.1 \times 10^{2} \mathrm{CFU} / \mathrm{g}\right.$ and $3.4 \times 10^{3} \mathrm{CFU} / \mathrm{g}$ for $\mathrm{TCC}$ and THC respecively) than the fish intestine's. Bacteria species such as Aeromonas hydrophila, Vibrio cholera, Shigella species were isolated from the water samples. Escherichia coli. Salmonella sp. Shigella sp. were isulated from the fish samples.
\end{abstract}

Keywords: Bacteriological profile, Hadejia reservoir.

\section{Introduction}

$\mathrm{H}$ adejia reservoir is one of the inland water bodies in Nigeria. Hadejia reservoir is a floodplain complex on the southern edge of the Sahel savanna in the northeastern Nigeria. Hadejia and Jamare rivers that supply this floodplain originate on the Jos Plateau and flow seasonally into Lake Chad. This area has long been noted for its importance to both year round native birds and European water birds that travel over the Sahara desert to this wetland to spend their winters. HadejiaNguru wetland has at least 89 species of freshwater fish (Chemonics, 2008). Due to all these, Hadejia wetland had an international attraction. As a natural water body it contains wide variety of microbial flora that originates from living and non-living plant and animals. Some of these microorganisms may be disease causing organisms to aquatic lives and to fish in particular (Cheesbrough, 2002, Agarwal 2005).

It has been estimated that 25,000 -deaths in a day are caused in developing countries either by direct consumption of polluted water or indirectly by contraction of diseases like malaria and bilharzia through disease vectors that live in polluted water (UNEP, 1991). Biological pollutants may also introduce pathogens into the aquatic environment that could lead to the death of aquatic food organisms such as fish and snails. These pathogens may be transferred to human beings through fish consumption (Agarwal, 2005). This study will help to provide baseline information on biological pollution status of Hadejia reservoir.

\section{Materials and Methods}

- Samples collection: Water samples for bacteriological study were collecled by dipping the sample bottle into the lake to a depth of $30 \mathrm{~cm}$ below water surface. The bottle was opened, allowed to fill up with water and then corked while still under water (APHA, 1985). This was labeled, kept in ice chest box and taken to the laboratory for bacteriological analysis. Fish samples were collected into a wide mouth sterile container and this was covered and kept in an ice chest box before taken to the laboratory for microbial analysis.

- Microbial Analysis: Quantilative analysis of bacterial populations in the fish and water samples were carricd out. Primary isolation which was followed by biochemical analysis was done on the isolates to identify the pathogens present in the water body and fish samples. 
Enumeration of total heterotrophic and total coliform bacteria in fish samples: The fish sample used was Oreochromis niloticus. This fish species was chosen because it is one of the commonest fish caught from the reservoir. The fish sample was washed thoroughly with sterile distilled water and dissected with the help of a sterile dissecting set. Fish gills and intestines were chosen on the basis that they have direct contact with water from the reservoir.

E A $1.0 \mathrm{~g}$ portion each of the gills and the intestines were pulverized in $9.0 \mathrm{mls}$ of sterile $0.1 \%$ peptone water using sterilized pestle and mortar. A serial dilution of each of these homogenates was prepared. A $0.1 \mathrm{ml}$ aliquot of the serially diluted homogenate was inoculated into sterilized plate count agar and Macconkey agar (for total heterotrophic bacterial count and total coliform count respectively), spread with a sterile bent glass rod (spread plates), and incubated at $37^{\circ} \mathrm{C}$ for 24 hours as previously done by Ogbondeminu et al. (1991) and Jones ( 1979). After incubation, the number of colonies werc counted, calculated and recorded as colony-forming units per gram (CFU/g) as shown in the formula below.

$$
\text { Colony - formingunits }(C F U)=\frac{\text { Colonycount } x \text { dilution factor }}{\text { Inoculumvolume }}
$$

Enumeration of total heterotrophic and total coliform bacteria in water samples: $1.0 \mathrm{ml}$ of water sample was serially diluted with sterile distilled water and $0.1 \mathrm{ml}$ of each serial dilution was plated on sterilized media (standard plate count technique) as described by Jones (1979). This was spread with a sterile bent glass rod and incubated at $370 \mathrm{c}$ for 24 hours. Media used were plate count agar and Macconkey agar for total heterotrophic bacterial count and total coliform count respectively. After incubation for $24 \mathrm{hr}$ the number of colonies were counted using colony counter, calculated and recorded as colony forming units per ml (CFU/ml) as shown in the formula above.

\section{Results}

- Bacterial enumeration of water samples: Enumeration of water samples show that at the inlet, the microbial load was low $\left(4.2 \times 10^{4} \mathrm{CFU} / \mathrm{ml}\right.$ and $\left.1.2 \times 10^{2} \mathrm{CFU} / \mathrm{ml}\right)$ for total heterotrophic and total coliform count respectively, These load witness a sharp increase $\left(2.4 \times 10^{6} \mathrm{CFU} / \mathrm{ml}\right.$ and $1.3 \times 10^{3} \mathrm{CFU} / \mathrm{ml}$ for total heterotrophic and total coliform count respectively) at sample point 2 . Microbial load at the outlet is lower $\left(3.1 \times 10^{5} \mathrm{CFU} / \mathrm{ml}\right.$ and $1.4 \mathrm{x}$ $10^{2} \mathrm{CFU} / \mathrm{ml}$ ) than that at the upper coarse. This result is seen in table 1 .

Tabie 1: Bacterial enumeration of water samples from Hadejia reservoir.

\begin{tabular}{ll|l}
\hline Sampling points & THC (CFU/ml) & TCC (CFU/ml) \\
1. (Inlet) & $4.2 \times 10^{4}$ & $1.2 \times 10^{2}$ \\
2. (landing site) & $2.4 \times 10^{6}$ & $1.3 \times 10^{3}$ \\
\hline 3. (landing site) & $3.5 \times 10^{6}$ & $1.4 \times 10^{3}$ \\
4. (Damsite) & $2.5 \times 10^{5}$ & $2.2 \times 10^{2}$ \\
5. (Outlet) & $3.1 \times 10^{3}$ & $1.4 \times 10^{2}$ \\
\hline
\end{tabular}

THC - Total heterotrophic count, TCC = Total coliform count, CFUiml - Colony forming unit per mills

a Bacterial enumeration of fish samples: Bacterial load in the fish intestines is higher $\left(3.1 \times 10^{4} \mathrm{CFU} / \mathrm{g}\right.$ and $3.5 \mathrm{x}$ $10^{3} \mathrm{CFU} / \mathrm{g}$ for total heterotrophic and total coliform count respectively) than that of gills $\left(3.4 \times 10^{3} \mathrm{CFU} / \mathrm{g}\right.$ and 2 . $\times 10^{2} \mathrm{CFU} / \mathrm{g}$ for total heterotrophic and total coliform count respectively). This result is seen in table 2 .

Table 2: Bacterial enumeration of fish samples from Hadejla reservoir

\begin{tabular}{l|l|l}
\hline Samples & THC (CFU/g) & TCC (CFU/g) \\
\hline Fish Gill (FG) & $3.4 \times 10^{3}$ & $2.1 \times 10^{2}$ \\
\hline Fish Intestines (FI) & $3.1 \times 10^{4}$ & $3.5 \times 10^{9}$ \\
\hline
\end{tabular}

IHC = Totai Heterotrophic Count, TCC $=$ Lotal Coliform Count, CFU/g $=$ Colony forming unit per gram. FG = Flsh gills, FI= Fish intestines.

Biochemical characterization of isolates from water samples: Result of biochemical analysis shows that nine $(64 \%)$ isolates out of fourteen isolates were Escherichia coli. Two $(14 \%)$ out of the fourteen isolates were Aeromonas hydwophila. Vibrio cholera and $S$. typhi were also isolated from the water samples. Although one isolate ( $7 \%$ ) each of these bacteria was isolated, it still calls for concern because the duo are strict pathogens of public health importance. This result is seen table 3 . 
Table 3: Results of biochemical characterization of isolates from water samples

\begin{tabular}{c|c|c|c|c|c|c|c|c|c|c}
\hline Isolates & Gram stain & Ind & MR & VP & CU & MO & $\mathrm{H}_{2}$ Son TSI & Amylase & OX & Organisms \\
\hline 1 & - & + & + & - & + & + & - & + & + & A.h \\
2 & - & + & + & - & - & + & - & - & - & E.C \\
3 & - & + & + & - & - & + & - & - & - & E.C \\
4 & - & - & + & - & + & - & + & - & - & S.t \\
5 & - & + & - & + & + & + & - & + & + & A.h \\
6 & - & + & - & - & + & + & - & + & + & V.C \\
7 & - & + & + & - & - & + & - & - & - & E.C \\
8 & - & + & + & - & - & + & - & - & - & E.C \\
9 & - & + & + & - & - & - & - & - & - & S \\
10 & - & + & + & - & - & + & - & - & - & E.C \\
11 & - & + & + & - & - & + & - & - & - & E.C \\
12 & - & + & + & - & - & + & - & - & - & E.C \\
13 & - & + & + & - & - & + & - & - & - & E.C \\
14 & - & + & + & - & - & - & - & - & - & E.C \\
\hline
\end{tabular}

Keys: Ind $=$ Indole, $M R=$ Meihyl ret', $V P=$ Voges proskauer, $C U=$ Citrite utilization, $M O-$ Motiity, $O X=$ Oxidase, A.h $=$ Aeromonas hydrophila, E.c. $=$ Escherichia coli, $S . t=$ Salmonella typhi, $S-$ Shigelli species, V.c $=$ Vibrin cholera.

- Biochemical characterization of isolates from fish gills: Biochemical analysis of isolates from fish gill shows that five (46\%) out of eleven isolates were Escherichia coli, three (27\%) were Aeromonas hydrophila, two (18\%) were Salmonella species and onc of the isolate is Shigella species. This result is scen in table 4.

- Biochemical characterization of isolates from fish intestines: Table 5 shows the result of biochemical characterization of isolates from the fish intestincs. Six $(46 \%)$ of the isolates were Lischerichia coli, four (31\%) were Aeromonas hydrophila. Two (15\%) out of the thirteen isolates were Salmonella species and one isolate was Shigella species.

Table 4: Results of biochemical characterization of isolates from fish gills

\begin{tabular}{l|c|c|c|c|c|c|c|c|c|c}
\hline Isolates & Gram stain & Ind & MR & VP & CU & MO & H2S on TSI & Amylase & OX & Organisms \\
\hline 1 & - & + & + & - & - & + & - & - & - & E.C \\
\hline 2 & - & - & + & - & + & + & + & - & - & S.Sp \\
3 & - & + & + & - & + & + & - & + & + & A.h \\
\hline 4 & - & + & + & - & + & + & - & + & + & A.h \\
5 & - & + & + & - & - & + & - & - & - & E.C \\
6 & - & - & + & - & + & + & + & - & - & S.Sp \\
7 & - & + & + & - & - & + & - & - & - & E.C \\
8 & - & + & + & - & - & + & - & - & - & E.C \\
9 & - & + & + & - & + & + & - & + & + & A.h \\
10 & - & + & + & - & - & - & - & - & - & S \\
\hline 11 & - & + & + & - & - & + & - & - & - & E.C \\
\hline
\end{tabular}

Keys: $A, h=$ Acromonas inyảrophila, E.c. = Escherichia coli, $5=$ Sirizella speties, $S . s p=$ Salmontelia species, Ind $=$ Indole, $M R-$ Meihy! red, $W 1=$ Voges proskater, $C L I=$ Citrate utilization, $M O-$ Mutility, OX = Oxidase.

Table 5: Result of biochemical characterization of isolates from fish intestines.

\begin{tabular}{c|c|c|c|c|c|c|c|c|c|c}
\hline Isolates & Gram stain & Ind & MR & VP & CU & MO & $\mathrm{H}_{2}$ S on TSI & Amylase & OX & Organisms \\
\hline 1 & - & + & + & - & - & + & - & - & - & E.C \\
2 & - & + & + & - & + & + & - & + & + & A.h \\
3 & - & - & + & - & + & + & + & - & - & S.Sp \\
4 & - & + & + & - & + & + & - & + & + & A.h \\
5 & - & + & + & - & + & + & - & + & + & A.h \\
6 & - & - & + & - & + & + & + & - & - & S.Sp \\
7 & - & + & + & - & - & + & - & - & - & E.C \\
8 & - & + & + & - & + & + & - & - & - & E.C \\
9 & - & + & + & - & - & - & - & - & - & S \\
10 & - & + & + & - & + & + & - & - & - & E.C \\
11 & - & + & + & - & + & + & - & + & + & A.h \\
\hline 12 & - & + & + & - & - & + & - & - & - & E.C \\
\hline 13 & - & + & + & - & - & + & - & - & - & E.C \\
\hline
\end{tabular}

Kuys: $A . h=$ Aeromonas hydrophila, E.c. $=$ Escherichia coli, $S=$ Shigella species, $S . s p-$ Salmondia species, ind = Indole, $M R=M e t h y l$ red, $V P=$ Voges, proskaner, $\mathrm{CU}=$ Citrate utilizaiton, $M O=$ Motility, $\mathrm{OX}-$ Oxidase.

\section{Discussion}

Quantitative analysis of bacterial isolates at the reservoir reveals lower load of bacteria at the inlet (sampling point 1) compared to the load at sampling points 2 and 3 (Table 1). This may be due to the fact that much anthropogenic activitics e.g. washing, bathing are carried out at sampling points 2 and 3 . This load tends to decrease as the water flows down the lower 
course. The outlet (sampling point 5) after the dam site has the lowest bact lerial load (Table 5). This difference in bacterial load agrees with the fact that the presence of bacteria iwwwn natural aquatic ecosystem is dependent upon the rate of contamination and the equilibrium that is established between bacterial proliferation in that environment and the rate of their climination (Lejeune et al., 2001).

Total coliform count in all the sampling point was higher than that of WHO (1992) standard $\left(1.0 \times 10^{3} \mathrm{CFU} / 100 \mathrm{ml}\right)$. This may be because most people in this part of the world see reservoirs, streams, rivers as dumping ground. Fish samples were seen to harbor Aeromonas hydrophila, Escherichia coli, Salmonella species and Shigella species. This result agrees with Mitchell, (1972) which states that fresh water fish may harbor human pathogens after exposure to contaminated water or food sources.

Fish intestines harbour more bacterial load (3.1 x $104 \mathrm{CFU} / \mathrm{g})$ than fish gills $(3.4 \times 103 \mathrm{CFU} / \mathrm{g})$. This result also agrees with Kasing et al. (1999) who observed in his study that the intestines of all lish examined harbored most number of bacterial species.

\section{Conclusion and Recommendation}

Bacteriological analysis of the reservoir reveals high load of bacteria and some of these are known to be pathogenic to both fish and humans. It is therefore recommended that fish caught from the reservoir should be properly boiled before consumption to avoid zoonotic diseases. High percentage of Escherichia coli calls for further study to identify the different strains of E. coli involved as some are known to be pathogenic e.g. F. coli 0157:H7. Contamination of water bodies should be discouraged through public enlightenment.

\section{REFERENCES}

Agarwal, S.K. (2005). Water Pollution. A.P.H. Publishing Corp. New Delhi. 276-314.

American Publie Health Association (1985). Siandard Method for the Examination of Water and Waste Water. APHA and WPCVE, 16th edition, Washington, D.C.

Banwort, G.J. (2004). Basic Food Microbiology, 2nd edition. CBS Publishers and Distributors. India. 54-505.

Cheesbrough, M. (2002). District Laboratary Manul for Tropical Countries. Part 2. Cambridge University Press. 143-147.

Chemonics International Inc. (2008). Nigeria biodiversity and tropical forestry assessment. Contract No. 620-c-00-05-00077-00.

Jatau, E.D. and Yakubu, S.E. (2004). Incidence of Aeromonas hydrophila in Tilapia obtained from Ahmadu Bello University Dam. Nigerian Jounnal of Scientific Research. 4(2). 86-90.

Jones, T.G. (1979). A Guide to methods of Estimating Microbial Numbers and Biomass in Fresh water. Biol. Association Scientific Publication, No. 39: $56-61$.

Kasing, A., Asiah, M.V. and Kumbang, J. (1999). Discribution of bacteria in tropical Freshwater Fish and Ponds. International Journal of Environmental Heaith Research, 9(4):285 - 292.

Lejeune, J.T., Besser, T.E., Rice, D.H. and Hancuck, D.D. (2001). Letlers in Applied Microbiology. 32: 316-320.

Mitchell, R. (1972). Water pollution Microbiology. 2ndedn. John Wiley \& Sons, Ine. 207-241.

Ogbondeminu, F.S., Madu, C.T. and Okaeme, N.A. (1991). Bucteriological aspects of cultured fingerlings of Clarias anguillaris in a hatchery complex in Nigeria. J. Aqua. Trop. 6: 45.

Zhao, S., Qaiyumi, S., Friedman, S., Singh, R., Foley, S.I., White, D.G., McDermou, P.F., Doukar, T., Bolin, C., Muuro, S., Baron, E.J. and Walker, R.D. (2003). Characterization of Salmonella entericser. Newport isolated from humans and food animals. $J$. Clin. Microbioi 41 (12): 5366-5371. 